\title{
Computer-aided estimates of drainage charges - A Dutch case study
}

\author{
S. W. Bie ${ }^{\star \star}$, A. F. van Holst ${ }^{1}$ and J. N. M. Stricker ${ }^{\star \star}$
}

1 Netherlands Soil Survey Institute, P.O. Box 98, Wageningen, the Netherlands

2 Waterschap Salland, P.O. Box 27, Olst, the Netherlands

Accepted: 17 January 1978

Key words: water drainage charges, lineprinter maps

\section{Summary}

When regional water management is regulated centrally on a cooperative basis, methods must be developed whereby drainage charges can be estimated from agreed and objective data. Reported here is a method to compute and map the charges to be levied, from data on altitude, supposed open water level by a given discharge and soil characteristics for available moisture. Internally, in the computer, independent 'maps' are compiled for each of the three attributes by computer mapping techniques. The area is split into a large number of small cells (here $12.5 \mathrm{~m} \times 15.5 \mathrm{~m}$ ), for each of which the altitude is estimated by interpolation from known spot heights.

For the same cells the supposed open water levels are approximated from interpolation from a number of calculated water levels in streams and ditches. Known watershed divides are introduced as barriers to interpolation. An existing soil moisture class map is split into the mentioned cells.

The three 'maps' provide for each cell the basic data required by an allocation algorithm which evaluates the value for altitude, water level and soil moisture class. For each cell the appropriate drainage charge class was determined.

A payment class map arises from the allocation, and can be printed on the computer lineprinter giving each class a distinguishing printing symbol.

The method is demonstrated for a 210-ha test area under the jurisdiction of the Regional Water Board Salland, the Netherlands. Further extension to include a cadastral map to allow automated invoicing procedures are discussed. The system is implemented on a CDC Cyber 72 computer and uses SYMAP (Harvard University, USA) as one module.

- Present address: Norwegian Computing Center, Forskningsvn 1 B, Oslo 3, Norway. ** Present address: Agricultural University, Department of Hydraulics and Catchment Hydrology, Nieuwe Kanaal 11, Wageningen, the Netherlands. 


\section{Introduction}

Management of regional water levels in the Netherlands is a cooperative effort. Farmers and other interests contribute in the costs of water management to a regional board. This authority is responsible for construction and maintenance of ditches, canals and pumping stations desirable for optimal water management.

Concerning farmland a recurring problem is to develop a sound basis on which to levy the charges required to support the centralized system by which the ground water levels are regulated to facilitate improved agricultural potential.

There would appear to be two approaches to this problem:

- a qualitative assessment by a committee as to the drainage charges to be imposed, based on field inspection of each cadastral parcel, if necessary supported by soil and water maps.

- a quantative estimate of drainage based on topographical, hydrological and soil attributes of the landscape.

The first method is currently practiced by most Dutch Water Boards. The Regional Water Board Salland (see inset map Fig. 1) uses aspects of both approaches.

The method is subjective, and thus open to objections from individual landholders. It is furthermore labour-intensive as frequent field visits are required for assessment and reassessment. Changes in regional water levels associated with locally revised drainage practices may require large-scale reassessments. Similarly, summer droughts of recent years have also raised the interest in using the drainage system in reverse mode - for water storage and infiltration. Current practice is also to treat cadastral parcels as the areal units, whereby within-parcel variations smaller than, for example, 1 ha are absorbed in an overall parcel estimate.

The quantitative approach considers the drainage requirement as a function of agreed attributes. The problem is then no longer to estimate the charges to be levied per cadastral parcel, but to estimate the values of a number of measurable attributes for a whole region. The actual drainage charges can then be estimated from agreed and objective data.

A computational problem arises, however, when the values of several attributes have to be compared simultaneously for a large area.

This paper outlines a quantitative method to objective levying of drainage charges as an alternative to current subjective methods. The proposed method has been tested in an area under the administration of the Regional Water Board Salland.

\section{Proposed method}

The cost $C$, per unit of area, of controlling the regional water level at any one location $i$, may be considered as a function of the altitude (above sea level) at $i$, futher denoted as $a_{i}$, the supposed open water level by a given discharge at $i\left(b_{i}\right)$ and the class of soil characteristics at $i\left(s_{i}\right)$.

If the difference between altitude and supposed open water level is large, the 
regional drainage system has to exert less work in creating favourable hydrological conditions in the area than if the difference is small. Similarly the effort required to drain a clay area is generally greater than a sandy area. However, the regional draining of low-lying clay areas may increase the likelihood of drought in higher lying sandy areas.

A simple model of this system is $C_{i}=f_{B}\left(a_{i}-b_{i}\right)$, where $f_{B}$ is the function of $\left(a_{i}-b_{i}\right)$, as to be established for the class of soil characteristics $s$ at $i$.

Assuming that an area $\mathrm{A}$ can be approximated as the sum of all locations n

$\Sigma \quad A_{i}$, where $A_{i}$ denotes the area of location $\mathrm{i}$, the total costs of draining area $\mathrm{i}=1$

$A, C_{A}$, can be calculated according to

$$
\mathrm{C}_{\mathrm{A}}=\sum_{\mathrm{i}=1}^{\mathrm{n}} \mathrm{A}_{\mathrm{i}} \cdot \mathrm{C}_{\mathrm{i}}=\sum_{\mathrm{i}=1}^{\mathrm{n}} \mathrm{A}_{\mathrm{i}} \mathrm{f}_{\mathrm{s}}\left(\mathrm{a}_{\mathrm{i}}-\mathrm{b}_{\mathrm{i}}\right)
$$

The task is now to compute $\left(a_{i}-b_{i}\right)$ and to ascertain $s_{i}$.

Assume that we have a topographic map of A. From this we may compute all and every $a_{i}$. Similarly assume that a map of the supposed open water level is available thus giving all and every $b_{i}$. Together with the soil moisture class map (all and every $s_{\mathrm{i}}$ ) we may calculate all and every $C_{\mathrm{i}}$ and thus $\mathrm{C}_{\mathrm{A}}$.

Logical operations performed on a series of map overlays constitute a major computational problem. De Gruijter \& Bie (1975) proposed a method whereby the area $\mathrm{A}$ is decomposed into a matrix of finite cells.

The values for each attribute for a cell can be combined by a suitable identification algorithm, whereby a cell is allocated to a class in an existing classification.

A contiguous pattern of cells approximate a subarea, and the sum of subareas constitutes the area A. De Gruijter \& Bie (1975), Bie (1976) and de Gruijter (1977) have demonstrated the application of this method for soil survey and geological survey. We have here modified their method for the estimation of drainage charges.

\section{The Evenbelt experiment}

Area

The experimental area Evenbelt occupies 210 ha of a total of 50000 ha falling under the jurisdiction of Regional Water Board Salland (see Fig. 1).

The area is part of the Salland Pleistocene coversand region, with $1.00-1.50 \mathrm{~m}$ of Late-Glacial aeolian sand overlying coarse Periglacial fluviatile material. The coversand is fine loamy sand to sandy loam, becoming loamier in lower lying areas (Knibbe, 1969). The relief is very gently undulating, $3.50-5.50 \mathrm{~m}$ above sea level, with a general SE to NW aspect. It is characterized by recurring patterns of elongated rises and depressions. These features also occur in Evenbelt.

In Evenbelt a brook valley crosses the north-eastern part. Throughout a moderately dense pattern of ditches drains the area in the north-westerly direction. 


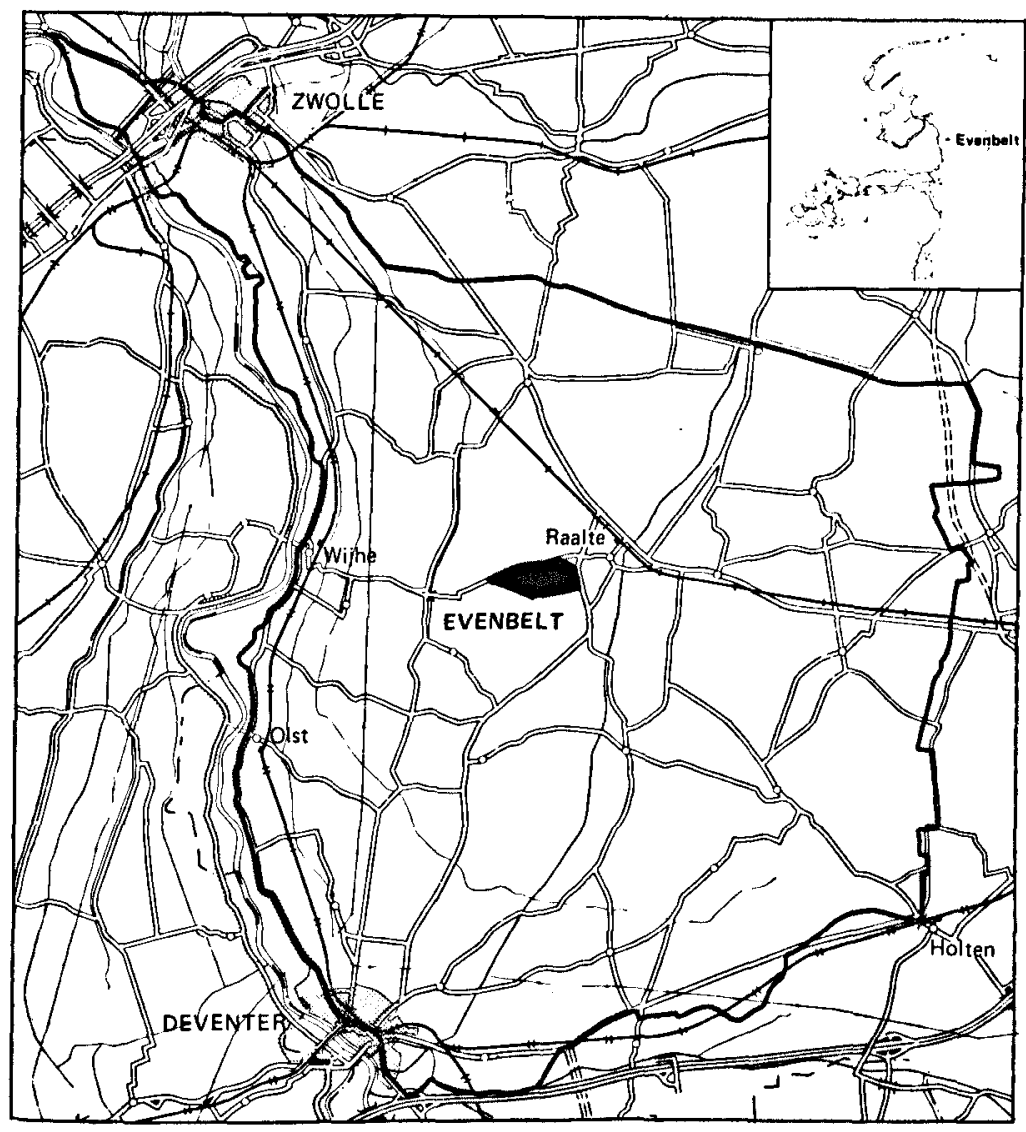

Fig. 1. Location map.

Humuspodzols dominate the higher areas, with 'beek' earth soils in the brook valley (de Bakker \& Schelling, 1966).

\section{Basic data}

For Evenbelt the following data were available:

1. 480 spot heights, in metres above sea level, on a topographic base made available by the Regional Waterboard Salland (Fig. 2).

2. Open water levels, in metres above sea level, at 107 points situated in streams and ditches, also originating from the Regional Water Board Salland (Fig. 3).

3. Outline of the local watershed divides as described by the Water Board (also Fig. 3).

4. A soil moisture class map (Fig. 4), compiled by Netherlands Soil Survey Institute, as a special purpose soil map for the Water Board. The survey, done with $11 / 3$ boreholes (to $1.20 \mathrm{~m}$ ) per ha at scale $1: 5000$, maps the physical characteristics of top- and subsoil being relevant for the estimation of available soil 




$\times \times \times \times \times$ watershed major ditch


Fig. 2, 3 and 4. Fragments of basic information used for the map of payment classes.

Fig. 2 (top). Spot heights (a) in metres.

Fig. 3 (middle), Water levels (b) in metres with watershed divides and open water (major and minor ditches).

Fig. 4. (bottom). Soil moisture class map (s), scale $1: 10000$. See for legend Fig. 5. 
Topsoil class

(decreasing soil moisture content $\longrightarrow$ )

\begin{tabular}{l|c|c|c|c|c|} 
& 4 & 3 & 2 & 1 \\
$\begin{array}{l}\text { Subsoil class } \\
\text { (decreasing } \\
\begin{array}{l}\text { capillary } \\
\text { conductivity) }\end{array}\end{array}$ \\
\cline { 2 - 6 }
\end{tabular}

Fig. 5. Soil moisture classes (A to D) as combinations of top- and subsoil classes.

moisture. Four classes were employed for the characterization of the topsoil, two classes for the subsoil. From the eight combinations a total of four soil moisture classes were generated (fig. 5).

\section{Data processing}

With a CDC Cyber 72 implementation of the computer mapping package SYMAP (Version 5.19) of Harvard University, USA, three cell maps were constructed for Evenbelt.

The cells are represented by a print symbol on the computer line printer. At the scale chosen (1:5000) each cell occupies approximately $3.1 \mathrm{~mm} \times 2.5 \mathrm{~mm}$ on the map or $15.5 \mathrm{~m} \times 12.5 \mathrm{~m}$ (= approx. $\left.194 \mathrm{~m}^{2}\right)$ in the field. This means approx. 52 cells/ha, supposed to be sufficiently accurate. In fact there is no real limit to the number of cells except the capacity of the computer.

The known spot heights were digitized on a Computervision Interact IV digitizing table, establishing their $\mathrm{x}, \mathrm{y}$ coordinates (in relation to an arbitrary origin) and reading off the height (a).

The SYMAP ISOLINE option was used (with default electives) to estimate the value $a_{i}$ for all cells constituting the area of Evenbelt. The resulting matrix was stored in the computer.

The water levels were similarly digitized, ascertaining their $\mathrm{x}, \mathrm{y}$ and $\mathrm{b}$ values at the measurement points. Watershed divides were digitized as strings of $\mathbf{x}, \mathbf{y}$ coordinates. The SYMAP ISOLINE option was used, with the watershed divides defined as impermeable barriers. Hereby no interpolation is done across the watershed divide; it is analogous to inserting an impermeable wall in the ground, preventing water from flowing across the divide. The $b_{i}$ values for all cells were again stored in the computer with the $\mathrm{x}, \mathrm{y}$ coordinate identification of the cell.

The soil moisture class map was digitized as strings of $\mathrm{x}, \mathrm{y}$ coordinates with the SYMAP CONFORMANT option, whereby the map is split into cells geographically similar to those for spot heights and water levels (Fig. 6). The $s_{\mathrm{i}}$ value here is the soil moisture class. Again the values were stored for each cell. 


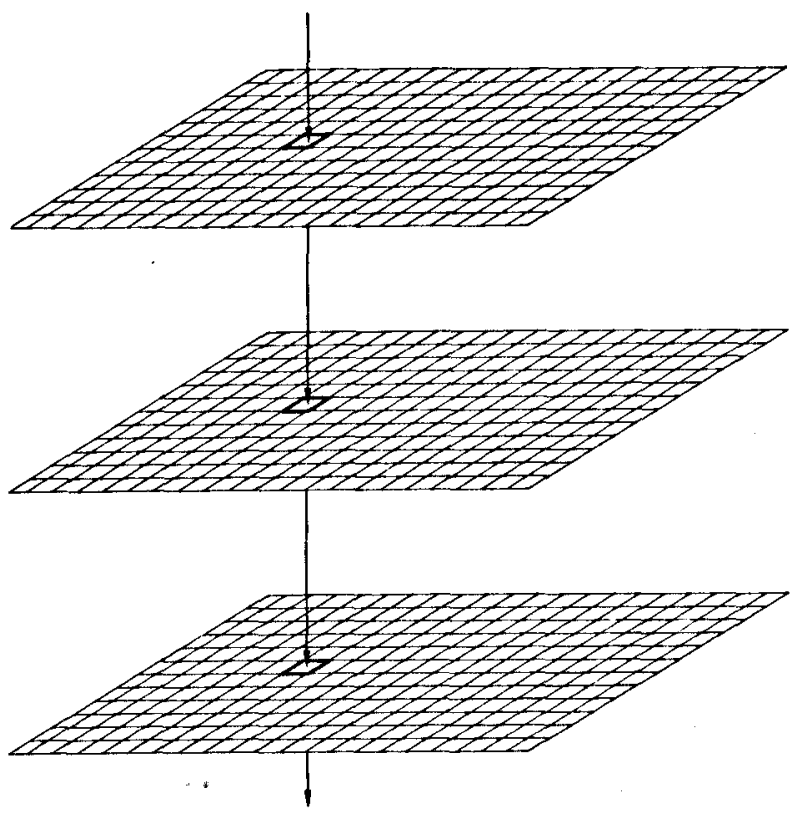

Fig. 6. Schematic overlays of three different maps, where a cell has the same geographical position on each map. Thus each cell can be represented by a set: $x, y, a_{i}, b_{i}, s_{i}$, where $x, y$ relate to the centre of the cell.

Table 1. Allocation algorithms for the payment classes.

\begin{tabular}{|c|c|c|}
\hline $\begin{array}{l}\text { Payment } \\
\text { class }\end{array}$ & $\begin{array}{l}\text { Attribute } \\
\left(a_{i}-b_{i}\right)\end{array}$ & $\begin{array}{l}\text { Soil moisture class } \\
\left(\mathrm{s}_{\mathrm{i}}\right)\end{array}$ \\
\hline \multirow[t]{3}{*}{1} & $\geqslant 60-<120$ & A \\
\hline & $\geqslant 60-<100$ & B \\
\hline & $\geqslant 50-<80$ & $\mathrm{C}$ \\
\hline \multirow[t]{5}{*}{2} & $\geqslant 50-<60$ & A \\
\hline & $\geqslant 120-<140$ & A \\
\hline & $\geqslant 100-<125$ & B \\
\hline & $\geqslant 80-<100$ & $\mathrm{C}$ \\
\hline & $\geqslant 50-<60$ & B \\
\hline \multirow[t]{7}{*}{3} & $\geqslant 140$ & A \\
\hline & $<50$ & A \\
\hline & $\geqslant 125$ & B \\
\hline & $<50$ & B \\
\hline & $\geqslant 100$ & $\mathrm{C}$ \\
\hline & $<50$ & $\mathrm{C}$ \\
\hline & $<80$ & $\mathrm{D}$ \\
\hline 4 & $\geqslant 80$ & $\mathrm{D}$ \\
\hline 5 & other & 一 \\
\hline
\end{tabular}




\section{Allocation algorithm}

The regional Water Board Salland proposed with respect to this experimental case to levy drainage charges according to 4-level charge structure (1-4). They proposed the allocation algorithms for the 4 payment classes as shown in Table 1 .

For this experiment a 5 th class was added: being available for cells that dit not fall in classes $1-4$ above.

With this algorithm each cell was allocated to a class. This is analogous to adding a 4th map under the pile of Fig. 6 . This resulting map of payment classes is reproduced in Fig. 7.

\section{Discussion}

The payment class map constructed (Fig. 7) represents a quantitative approach to the estimation of drainage charges. However, it need not be an end product. It is possible although not done in this experiment to add a further overlay, the cadastral map, and then to sum the number of cells (thus area) for each cadastral unit. A file is then created which takes the form, for example:

Cadastral unit B123: 0.54 ha class $1,0.16$ ha class 2 ,

0.23 ha class $3,2.80$ ha class 4 .

A correspondence list may be made linking the rate payer (usually landowner) to the cadastral units, for example:

Mr J. P. Smit, Veldweg 12, Raalten

: Cadastral units B123, B124, B125.

etc.

At any time the Water Board may wish to attach monetary values to the classes. Proposed 1977 rates in Salland are

Class 1: Dfl. 130 per year per ha;

Class 2: Dfl. 91 per year per ha;

Class 3: Dfl. 52 per year per ha;

Class 4: Dfl. 26 per year per ha.

It is also possible to calculate rates not in classes but as a continuous variable. This is appealing from a scientific point of view, however less transparent to the rate payer. The rate to be paid, $\mathrm{R}$, can be calculated as $\mathrm{R}=f(\mathrm{a}, \mathrm{b}, \mathrm{s})$.

The invoicing system may be linked to the resulting file allowing for automatic billing procedures.

The experiment reported here terminated at the stage of the payment class map; its main purpose being to demonstrate the feasibility of an objective approach to the calculation of these classes.

The Netherlands Soil Survey Institute also possesses computer-based interactive map editing facilities whereby changes in the payment class map (or any other map) may be effected. Adjustments required in the map may thus be introduced, for example, to take account of local information not available initially for the automated map construction or to improve on imperfections in the map compilation process.

If the unit cost of water charges were to be altered, single multiplication 


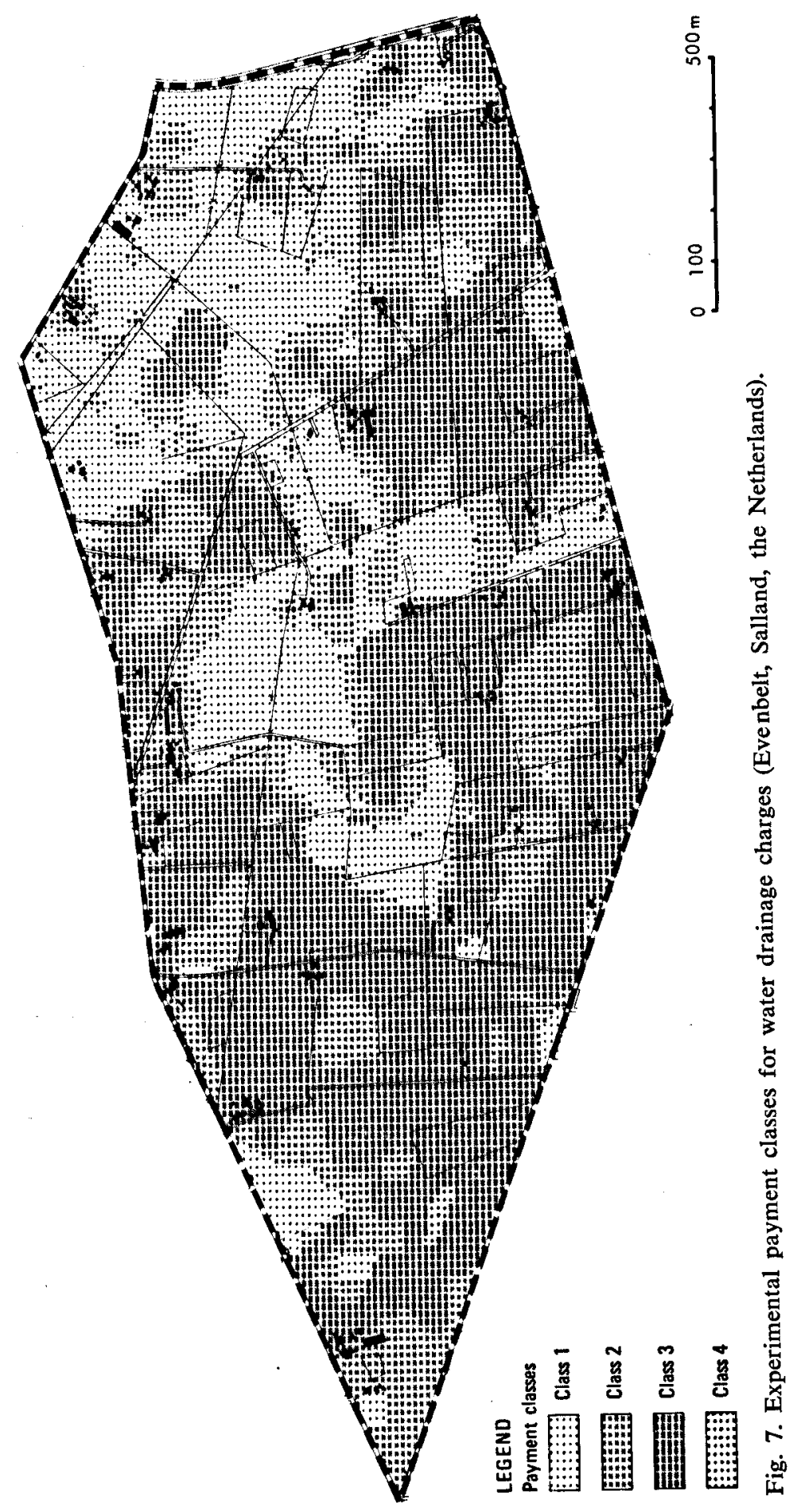


achieves this without any need to recalculate the payment classes or interfere with the basic data.

If the charge structure were to be changed, establishing new rules for drainage levies, only the class allocation algorithms need to be updated. The values of the basic soil attributes remain unaltered. Reprocessing of these data with the new algorithms is an inexpensive exercise.

Similarly, if the values of a basic attribute were to be changed, for example by modifications in water management, only the relevant map, here water level map, has to be recompiled. It is thus unnecessary to resurvey the area for altitude and soil moisture information.

This flexibility may prove a major asset in a production environment.

\section{Conclusion}

The proposed method represents a set of logical overlays to produce estimates of drainage charges. The production of a map of the payment classes has proved technically feasible.

The 'overlay method' offers considerable advantages as more objective and less labour intensive than current procedures. In addition the user may choose any cell size deemed appropriate for the purpose, on the basis of the precision of the basic data available. Further research into the choice of cell size is recommended.

The flexibility of the 'overlay method' allows changes to be rapidly introduced in one or more of the classification variables without altering the basic data. Furthermore it facilitates the introduction of new or changed values in the basic data without creating the need for an overall recompilation.

This use of the 'overlay method' exemplifies the general applicability of this display procedure for quantities derived from multivariate spatial data.

\section{Acknowledgments}

B. Bunschoten, J. Gerkes, W. G. J. J. Hamer and N. J. C. M. Hofstede prepared the material for computer processing. We are also grateful for comments from officers of the Water Board Salland, especially H. Siebering, and from J. J. de Gruijter on earlier versions of this paper.

\section{References}

Bakker, H. de \& J. Schelling, 1966. Systeem van bodemclassificatie voor Nederland. De hogere niveaus, Pudoc, Wageningen.

Bie, S. W., 1976. New methodologies for geological surveys. Computers \& Geosci. 2: 341-344.

Gruijter, J. J. de, 1977. Numerical classification of soils and its application in survey. Agric. Res. Rep. No. 855. Pudoc, Wageningen.

Gruijter, J. J. de \& S. W. Bie, 1975. A discrete approach to automated mapping of multivariate systems. Proceedings of a Technical working session on Automated Cartography. International Cartographic Association ITC, Enschede, p. 17-28.

Knibbe, M., 1969. Gleygronden in het dekzandgebied van Salland. Bodemk. Stud. No. 8. Stichting voor Bodemkartering, Wageningen. 